\title{
Ancient metasomatism recorded by ultra-depleted garnet inclusions in diamonds from De Beers Pool, South Africa
}

\author{
Anetta Banas ${ }^{1,2}$, Thomas Stachel ${ }^{1}$, Nobumichi Shimizu ${ }^{3}$, David Phillips ${ }^{4}$, \\ K. S. (Fanus) Viljoen ${ }^{5}$, Jeff W. Harris ${ }^{6}$ \\ ${ }^{1}$ University of Alberta, Edmonton, Canada, \\ ${ }^{2}$ Apex Geoscience Ltd., Edmonton, Canada, \\ ${ }^{3}$ Woods Hole Oceanographic Institute, Woods Hole, USA, \\ ${ }^{4}$ University of Melbourne, Melbourne, Australia, \\ ${ }^{5}$ Johannesburg University, Johannesburg, South Africa, \\ ${ }^{6}$ University of Glasgow, Glasgow, Scotland
}

\section{Introduction}

Peridotitic garnet inclusions in diamonds from the De Beers Pool mines (Kimberley area, South Africa) represent samples from an extremely depleted mantle source with $94 \%$ of the garnets being harzburgiticdunitic in paragenesis (Figure 1 and Phillips et al., 2004). Olivine inclusions are characterized by very high Mg-numbers (average: 94.6) and a large number of garnet inclusions $(\sim 72 \%)$ have $\mathrm{CaO}$ contents of less than $1.8 \mathrm{wt} \%$. These observations suggest that initial melt depletion in the protoliths of the subcratonic lithospheric mantle beneath Kimberley exceeded orthopyroxene exhaustion (i.e. $\geq 50 \%$ melt extraction) and hence went much farther than typically observed for cratonic peridotites world wide (Figure 1).

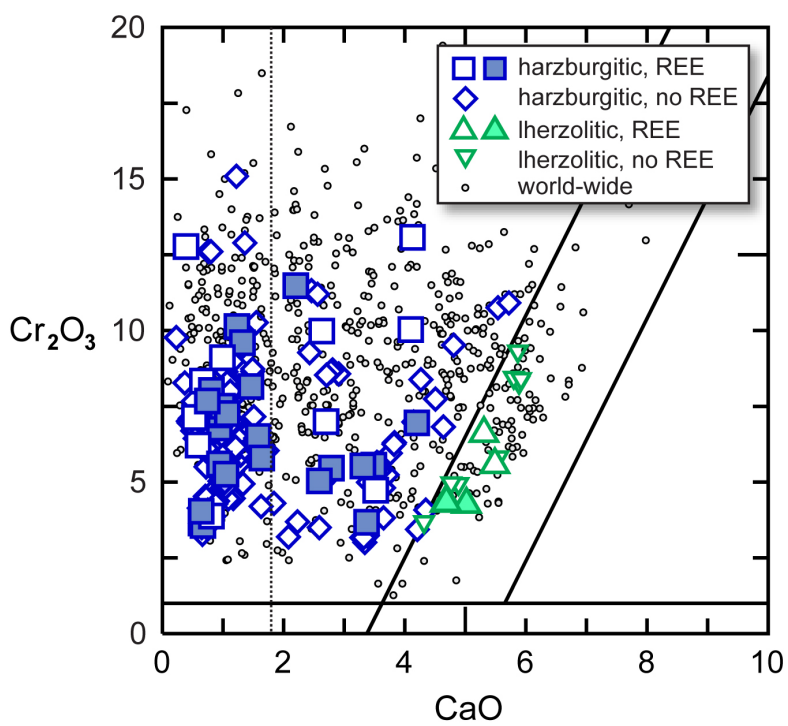

Figure $1 \mathrm{Cr}_{2} \mathrm{O}_{3}$ vs. $\mathrm{CaO}$ (wt\%) of De Beers Pool peridotitic garnet inclusions. Lherzolitic field after Grütter et al., (2004). Filled symbols refer to garnets co-existing with orthopyroxene, allowing determination of equilibration conditions. Dashed line $(1.8 \mathrm{wt} \% \mathrm{CaO})$ limits ultra-depleted harzburgitic/dunitic garnet compositions (Grütter et al. 1999).

\section{Garnet Rare Earth Element Patterns}

Analyses of rare earth and other trace elements show that the De Beers Pool garnet inclusions, despite their ultra depleted major element composition, were affected by metasomatic enrichment processes similar to those recorded by diamond inclusions worldwide. The garnets show a wide range of REE concentrations and variable sinuosity of chondrite normalized abundance patterns which may be subdivided into six main groups (Figure 2).

Garnets with high Ti contents show an overall increased abundance of REE although their $R E_{N}$ patterns are similar to low-Ti garnets. For De Beers Pool, sinuosity of garnet $\mathrm{REE}_{\mathrm{N}}$ patterns generally decreases with increasing fertility (i.e. higher $\mathrm{Ca} \mathrm{Ti}$, $\mathrm{Fe}, \mathrm{Y}$, and $\mathrm{Zr}$ ); a distinction between the $\mathrm{REE}_{\mathrm{N}}$ signatures of harzburgitic and lherzolitic garnets is, nevertheless, not possible.

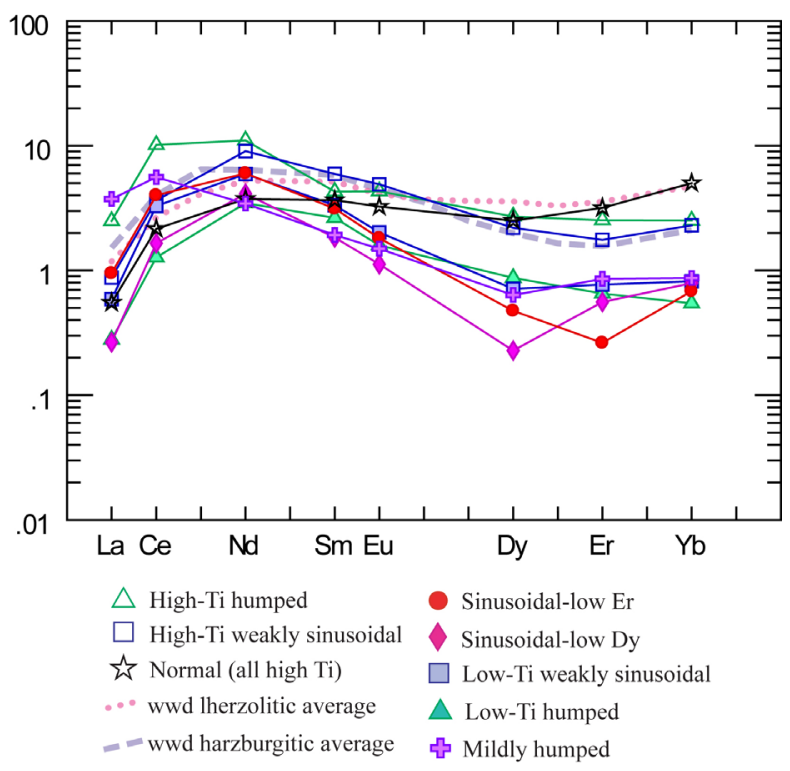

Figure 2 Average $\mathrm{REE}_{\mathrm{N}}$ (suffix $\mathrm{N}$ denominates normalisation to the C1-chondrite composition of McDonough and Sun, 1995) compositions for the six groups of patterns observed among De Beers Pool garnet inclusions. Worldwide average compositions for harzburgite (dashed line) and lherzolite (dotted line) garnet inclusions (Stachel et al. 2004) are shown for reference. High-Ti garnets straddle worldwide averages, whereas the low-Ti garnets plot well below the harzburgitic average. 


\section{Geothermobaromerty}

The recovery of coexisting garnet-orthopyroxene from 35 De Beers Pool diamonds provides pressure temperature constraints on conditions of diamond formation (Harley 1984; Brey and Köhler 1990). The average pressure-temperature conditions for nontouching inclusion pairs are $6.3 \mathrm{GPa}$ and $1200^{\circ} \mathrm{C}$, whilst touching inclusion pairs equilibrated at $\sim 5.4$ $\mathrm{GPa}$ and $1080^{\circ} \mathrm{C}$ (Phillips et al., 2004). The nontouching inclusion pairs define paleo-geotherm equivalent to $40 \mathrm{~mW} / \mathrm{m}^{2}$ surface heat flow, which is slightly hotter than the $38 \mathrm{~mW} / \mathrm{m}^{2}$ paleo-geotherm derived from mantle xenoliths in Cretaceous Group 1 kimberlites. The garnets examined for their trace element contents cover the whole pressure (4.0-7.5 $\mathrm{Gpa})$ and temperature range $\left(1000-1325^{\circ} \mathrm{C}\right)$ recorded by the De Beers Pool data set. Linear correlations between P-T conditions and REE concentrations are not evident but broad associations can be made. The low-Ca $(<1.8 \mathrm{wt} \%)$ garnets indicate crystallisation over a wide depth range. Garnets with higher $\mathrm{Ca}$ concentrations, and high REE, Ti, Y and $\mathrm{Zr}$ contents are restricted to shallower depths (equivalent to $<6 \mathrm{Gpa}$ and $<1100^{\circ} \mathrm{C}$; Figure 3 ).

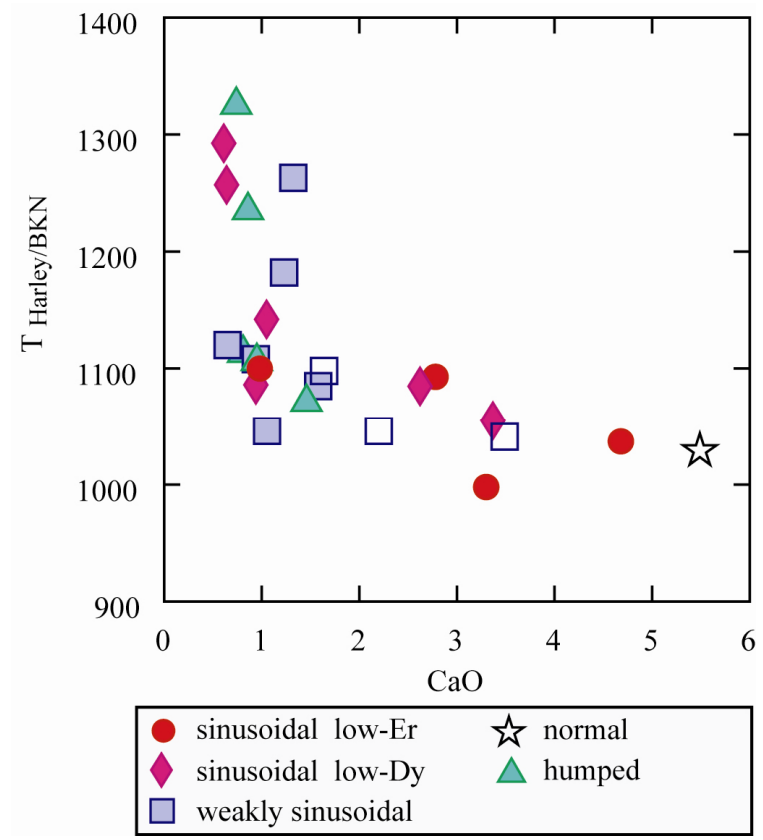

Figure 3 Temperature estimates based on garnet-opx equilibria (iterative calculations using $\mathrm{T}_{\text {Harley }}$ and $\mathrm{P}_{\mathrm{BKN}}$ ) plotted against $\mathrm{CaO}(\mathrm{wt} \%)$ in garnet. High-Ti garnets (open symbols) are restricted to lower temperatures (and pressures) whereas low-Ti garnets (solid symbols) span the whole temperature (and pressure) range. Symbols refer to the six basic types of $\mathrm{REE}_{\mathrm{N}}$ patterns shown in Figure 2.

\section{Discussion}

The REE signatures of De Beers Pool garnet inclusions indicate that their source region was affected by two phases of metasomatic modification. LREE enrichment is preserved in all garnets and indicates interaction with a fluid of highly fractionated character. The variable
LREE concentrations of the garnet inclusions reflects progressively increasing LREE/HREE ratios in an upward percolating fluid during equilibration with (or precipitation of) garnet. This metasomatic event was pervasive and affected the entire depth section of the lithosphere represented by the De Beers Pool inclusions.

A second phase of metasomatic enrichment through melts carrying high field strength elements (including HREE) and major elements ( $\mathrm{Ca}$ and $\mathrm{Fe}$ ) affected only a portion of the diamond source region and was restricted to depth shallower than $180 \mathrm{~km}$.

Diamond precipitation was likely associated with both styles of metasomatic re-enrichment. The similarity of lherzolitic and harzburgitic $\mathrm{REE}_{\mathrm{N}}$ patterns and their similarly variable REE concentrations suggests diamonds of both parageneses were formed concurrently.

\section{Conclusions}

The major element composition of olivine and garnet inclusions in diamonds from De Beers Pool documents diamond formation preferentially in ultra-depleted, likely dunitic sources. This signature of extreme depletion is not apparent from studies of peridotite xenoliths in Group 1 kimberlites from the same area (e.g. Richardson et al. 1984; Simon et al. 2007) and highlights the unique role that inclusions in diamond as time capsules dating back as far as the Mesoarchean - may play in unraveling the history and mechanisms of early lithosphere formation.

Despite their highly depleted major element composition, garnet inclusions from De Beers Pool are invariably affected by metasomatic overprint. Metasomatic enrichment through an agent with very high LREE/HREE affected the entire diamond stable lithospheric mantle beneath Kimberley and is also documented in the suite of garnet inclusions used by Richardson et al. (1984) to establish a Mesoarchean formation age $(\sim 3.2 \mathrm{Ga})$ for harzburgitic paragenesis diamonds from De Beers Pool. A second style of metasomatic re-enrichment, associated with lower LREE/HREE and affecting major elements as well, was less pervasive and appears to be absent in diamond samples derived from the deepest portions of the Kaapvaal lithosphere $(>180 \mathrm{~km})$. This second metasomatic event either was spatially constrained (e.g. to the vicinity of melt channels) or occurred subsequent to the formation of diamonds with highly LREE enriched subcaclic garnet inclusions at $\sim 3.2 \mathrm{Ga}$.

In any case, the observation that even the most depleted samples of original Archean lithospheric mantle invariably are affected by secondary reenrichment in incompatible trace elements re-affirms a genetic link between mantle metasomatism and diamond formation. 


\section{Refrences:}

Brey, G.P. and Köhler, T., 1990. Geothermobarometry in four-phase lherzolites II. New thermobarometers, and practical assessment of existing thermobarometers. Journal of Petrology, 31: 1353-1378.

Grütter, H.S., Apter, D.B. and Kong, J., 1999. Crust-mantle coupling: evidence from mantle-derived xenocrystic garnets. In: J.J. Gurney, J.L. Gurney, M.D. Pascoe and S.H. Richardson (Editors), The J.B. Dawson Volume, Proceedings of the VIIth International Kimberlite Conference. Red Roof Design, Cape Town, pp. 307-313

Grütter, H.S., Gurney, J.J., Menzies, A.H, Winter, F. (2004) An updated classification scheme for mantle-derived garnet, for use by diamond explorers. In: Mitchell, R. H., Grütter, H.S., Heaman, L.M., Scott Smith, B.H., Stachel, T. (eds) Proceeding of the $8^{\text {th }}$ Internationl Kimberlite Conference, Lithos, vol.77, no.1-4, pp.841-857

Harley, S.L., 1984. An experimental study of the partitioning of iron and magnesium between garnet and orthopyroxene. Contributions to Mineralogy and Petrology, 86: 359-373.

McDonough, W.F. and Sun, S.-S., 1995. The composition of the Earth. Chemical Geology, 120: 223-253.

Phillips, D., Harris, J.W. and Viljoen, K.S., 2004. Mineral chemistry and thermobarometry of inclusions from De Beers Pool diamonds, Kimberley, South Africa. Lithos, 77: 155-179.

Richardson, S.H., Gurney, J.J., Erlank, A.J. and Harris, J.W., 1984. Origin of diamonds in old enriched mantle. Nature, 310(5974): 198-202.

Simon, N.S.C., Carlson, R.W., Pearson, D.G. and Davies, G.R., 2007. The origin and evolution of the Kaapvaal cratonic lithospheric mantle. Journal of Petrology, 48(3): 589-625.

Stachel, T., Harris, J.W. and Brey, G.P., 1999. REE patterns of peridotitic and eclogitic inclusions in diamonds from Mwadui (Tanzania). In: J.J. Gurney, J.L. Gurney, M.D. Pascoe and S.H. Richardson (Editors), The P.H. Nixon Volume, Proceedings of the VIIth International Kimberlite Conference. Red Roof Design, Cape Town, pp. 829-835.

Stachel, T., Brey, G.P. and Harris, J.W., 2000. Kankan diamonds (Guinea) I: from the lithosphere down to the transition zone. Contributions to Mineralogy and Petrology, 140: 1-15.

Stachel, T. et al., 2004. The trace element composition of silicate inclusions in diamonds: a review. Lithos, 77: 119. 